\title{
Impact of regional bans of highly hazardous pesticides on agricultural yields: the case of Kerala
}

\author{
Aastha Sethi ${ }^{*} \mathbb{0}$, Chien-Yu Lin², Indira Madhavan ${ }^{3}$, Mark Davis $^{1}$, Peter Alexander ${ }^{4}$, Michael Eddleston ${ }^{1 \dagger}$ and \\ Shu-Sen Chang $2,5,6+$
}

\begin{abstract}
Background: Removing highly hazardous pesticides from agricultural practice in low- and middle-income countries is crucial to ensuring community and environmental health and occupational safety of farmers. However, the approach has been challenged as threatening food production, despite evidence from Asian countries that curbing agricultural use of highly hazardous pesticides does not affect crop yields. In 2011, the state of Kerala, India, banned 14 highly hazardous pesticides resulting in a marked reduction in deaths from pesticide poisoning.

Objective: We aimed to determine whether the Kerala pesticide bans impacted agricultural yields.

Methods: We collected data on agricultural production, area under cultivation, and rainfall, published by the Kerala state agricultural department from 2004 to 2018 for eight key crops that had been treated with the banned pesticides. Trends in crop yields (total production/area under cultivation) and rainfall across 14 districts in Kerala were aggregated and analysed using joinpoint regression. These trends were evaluated to ascertain possible associations with the pesticide bans.

Results: The joinpoint regression analyses showed no evidence for any change in yield trends for any of the eight crops in the year of the pesticide bans (2011), or the subsequent year (2012), suggesting a negligible impact of the bans on crop yields. Steady trends of predominately reductions in overall rainfall, without any change around the time of the pesticide bans, was observed in Kerala throughout the period. No evidence of district-level changes in rainfall that might have offset any potential adverse impacts of the pesticide bans on crop yields was noted. Fluctuations in yield until 2018 could be explained by variation in rainfall, changes in land use, and agricultural policies.

Conclusion: We found no evidence of an adverse effect on agricultural yields in Kerala that could be attributed to bans of highly hazardous pesticides. This work provides further evidence that such pesticides can be withdrawn from agricultural use without affecting yields. Further studies are required for the whole of India after the national bans of 12 pesticides in 2018 to identify state-level effects of the bans.
\end{abstract}

Keywords: Pesticide regulation, Pesticide ban, Agricultural output, Food production, Pesticide poisoning, Kerala

*Correspondence: asethi@ed.ac.uk

${ }^{\dagger}$ Michael Eddleston and Shu-Sen Chang have contributed equally to the manuscript

${ }^{1}$ Centre for Pesticide Suicide Prevention, University of Edinburgh, Edinburgh, UK

Full list of author information is available at the end of the article

\section{Introduction}

Pesticides pose threats to human health and wellbeing [1]. They cause harm to the environment, pollute food and water, and are a threat to beneficial bio-diversity due to negative effects on non-target species $[2,3]$. Stricter controls regulating the usage of highly hazardous 
pesticides can have a range of benefits: reducing pesticide suicide rates in farming communities $[4,5]$, preventing harm caused to human health by chronic exposures [6, 7], and preserving natural ecosystems [2]. Pesticide regulation and bans are frequently controversial as they are believed to potentially reduce crop yields. However, field studies from India have shown that sustainable methods, such as integrated pesticide management (IPM) and agroecology, do not significantly reduce yields or increase farmers' costs in comparison to conventional farming techniques [8-11].

Pesticide suicide is a particular problem in rural Asian communities, killing around 110,000-168,000 people each year worldwide [12]. India officially reported 24,064 deaths in 2019 from pesticide self-poisoning [13], although community level studies indicate that the actual number is probably around three times higher, at around 70,000 per year $[12,14]$. Many pesticide suicides can be prevented by means restriction [15] - by banning highly hazardous pesticides [16-18]-as shown in Sri Lanka [4, 19], Bangladesh [5], India [20], South Korea [21], and Taiwan [22]. Self-poisoning with much less toxic pesticides after bans greatly reduces the risk of death [17] as observed in high-income countries where few people have access to pesticides, most self-poisoning is with medicines, and few people die from self-poisoning [23].

Chronic exposure to pesticides among farm workers has been linked to health problems such as respiratory disorders, neurodegenerative disorders, and some types of cancer $[6,7,24]$. Indian field studies have reported other adverse health effects among farm workers such as muscle pain, headaches, blurred vision, tremors, sleep disorders, and cardiac problems [25-27]. Pesticide residues in food have been linked to chronic health effects such as immune suppression, hormone disturbance, reproductive defects, and cancers, even at low exposure dose [28-31]. Food samples in India have been found to exceed maximum permissible limits $[32,33]$ which indicates that bans on highly hazardous pesticides need to be scaled up nationally.

The harmful effects of hazardous pesticides on the environment have been a cause of concern among UN agencies and the international community [34, 35]. Many hazardous pesticides have been linked to environmental pollution, and are a threat to beneficial bio-diversity due to devastating effects on non-target species such as honeybees and earthworms [2]. Spraying of pesticides leads to air, soil, and, water pollution which can be prevented by using safer formulations or natural farming techniques [36]. Organic farming fields have five times higher plant species richness, 20 times higher pollinator species, and higher earthworm abundance as compared to conventional fields [37, 38].
While environmental harms and public health risks posed by pesticides that can be curtailed through prohibiting their use, a major objection to pesticide regulation to restrict or ban sales is the concern of potential impact on agricultural yields [39-41]. Were yields to be reduced, this would negatively affect farming community livelihoods, be reflected in changes to trade in food commodities reducing regional food self-sufficiency and increasing prices, and ultimately impact food security [42]. However, studies from Bangladesh, South Korea, Sri Lanka, and Taiwan indicate that pesticide bans do not affect agricultural output [21, 22, 43, 44]. Moreover, field studies from other regions in India have shown that sustainable methods, such as IPM and agroecology, do not lead to significant reductions in yields or significant increases in farmers' costs in comparison to conventional farming techniques [8-11].

After an initial national ban of 16 pesticides in 2018, the Indian government proposed to ban the use of 27 pesticides in 2020 (Box 1) [45]. This was heavily opposed by the pesticide industry citing concerns regarding decline in agricultural output and is still under review [46, 47]. In 2011, the state government of Kerala banned 14 highly hazardous pesticides (Box 1), while recommending substitutes for each banned pesticide [48]. The state had previously banned the organochlorine insecticide, endosulfan, in 2005, 6 years ahead of nationwide Indian bans [20]. These bans have resulted in a fall in pesticide poisoning deaths in the state [20], but their effect on agriculture has not been studied.

We here aimed to assess the effects of the 2011 pesticide bans on the yields of major crops in Kerala. Analysis of state-level yield trends may contribute to national pesticide regulation policy leading to elimination of highly hazardous pesticides from Indian agriculture. The national ban, if implemented, will be a significant step towards reducing pesticide suicide deaths and elevating agricultural safety standards by safeguarding the health of farmers and agricultural labours, who comprise approximately half of the Indian population [49].

\section{Methods}

\section{Research setting}

Kerala is the smallest state in south India and has significantly better human development indicators with higher rates of literacy, lower infant mortality rates, and a higher life expectancy at birth than the national average [50]. $16.7 \%$ of the population is dependent on agriculture and allied activities [51] even though structural changes have led to a constant decline in the agricultural sector's contribution to state gross domestic product which is coupled with a constant decline in area under cultivation for food crops in favour of cash crops in the state [51]. 
Plantation cash crops (tea, coffee and rubber) account for $62.1 \%$ and food crops (rice, pulses, and tapioca) account for $10.2 \%$ of the area under cultivation [51].

\section{Data collected}

We collected data on rainfall, crop production, and area under cultivation for the following crops in Kerala as their output data are routinely collected, and one or more of the banned pesticides were commonly used in their production [48]: banana (Musa spp.), plantain (Musa paradisiaca; nendran plantain being the main local variety), cashew (Anacardium occidentale), cardamom (Elettaria cardamomum), rice/paddy (Oryza sativa indica), pulses (mainly red gram and gram; Cajanus cajan/Cicer arietinum), sweet potato (Ipomoea batatas), and tapioca/cassava (Manihot esculenta). These crops account for an estimated $20 \%$ of the total cultivated area in the state [51].

Data were based on crop surveys conducted by the Department of Economics \& Statistics (DES), Government of Kerala [52]. Under the scheme for improvement of crop statistics, an annual review of the crop statistics system is published jointly by the DES and the National Statistical Office to ensure efficiency and accuracy in agricultural data collection through technical checks to strengthen the system. Annual economic reviews published by the Kerala state government were used to collect data regarding changes in rainfall that might affect yield [53].

Annual data for crop production and area under cultivation were compiled for the eight selected crops from across Kerala's 14 districts for the years 2004 until 2018, providing data for 6-7 years on either side of the 2011 pesticide bans. Average area under cultivation (hectare) and total crop production (tonnes) for the periods before and after the pesticide bans (2004-2011 and 2012-2018) and percent change between the two periods were calculated. Due to fluctuations in area under cultivation and subsequent crop production, yield was the measure used to analyse trends. Yield was calculated as total production/area under cultivation $(\mathrm{kg} /$ hectare).

\section{Statistical analysis}

We conducted joinpoint regression analysis to examine time trends in the yields of eight types of crops in Kerala during the period 2004-2018. We also used joinpoint regression to examine whether there was any evidence for a change in rainfall coinciding with the year of pesticide bans implementation to consider the possibility of increased rainfall offsetting adverse effects from the bans.

The joinpoint regression analysis involves no a priori assumption of when the impact of an intervention on outcomes would occur. Trend data are characterised by a combination of contiguous linear segments and joinpoints' (points at which trends change) in joinpoint regression models [54]. For the observations, $\left(x_{1}, y_{1}\right), \ldots$, $\left(x_{n}, y_{n}\right)$, where $x_{1} \leq \ldots \leq x_{n}\left(x_{\mathrm{i}} \mathrm{s}\right.$ indicate time points, e.g. calendar years, and $y_{\mathrm{i}} \mathrm{s}$ are the yields of eight crops or rainfall), the model can be written as:

$$
E[y \mid x]=\beta_{0}+\beta_{1} x+\delta_{1}\left(x-\tau_{1}\right)^{+}+\cdots+\delta_{k}\left(x-\tau_{k}\right)^{+},
$$

where $k$ is the number of joinpoints, $\tau_{k}$ are the unknown joinpoints and $a^{+}=a$ for $a>0$ and 0 otherwise. For example, if there is one joinpoint in year 2011 for the study period 2004-2018, the model is $E[y \mid x]=\beta_{0}+\beta_{1} x+\delta_{1}(x-$ 2011) for the period 2011-2018 and $E[y \mid x]=\beta_{0}+\beta_{1} x$ for 2004-2011.

The joinpoint regression analysis compares a series of joined line segments to identify the combination that fits the trend data best using a permutation method. A procedure is employed to determine the number of joinpoints (i.e. $k$ ). For example, to determine up to two joinpoints, the procedure first tests the hypothesis of no change $\left(\mathrm{H}_{0}\right.$ : $E[y \mid x]=\beta_{0}+\beta_{1} x$; i.e. $\left.k=0\right)$ against the alternative hypothesis of two joinpoints $\left(\mathrm{H}_{\mathrm{a}}\right.$ : there exist $\tau_{1}$ and $\tau_{2}$ and $\tau_{1}<\tau_{2}$ such that $E[y \mid x]=\beta_{0}+\beta_{1} x+\delta_{1}\left(x-\tau_{1}\right)^{+}+\delta_{2}\left(x-\tau_{2}\right)^{+}$; i.e. $k=2$ ). If the null hypothesis is rejected, then the similar procedure is applied to test the null hypothesis of one joinpoint $(k=1)$ against the alternative of two joinpoints $(k=2)$. Otherwise, the null hypothesis of no change $(k=0)$ is tested against the alternative of one joinpoint $(k=1)$. This approach is aimed to identify the smallest number of joinpoints supported by the trend data.

The test statistic was obtained by the grid search method suggested by PM Lerman [55]. The p-values and 95\% confidence intervals (CIs) were computed using the permutation procedure for the following parameters: the number of joinpoints $(k)$, the location of the joinpoints $\left(\tau_{1}, \ldots, \tau_{k}\right)$ and the regression coefficients, $\delta_{1}, \ldots, \delta_{k}$, which indicated the magnitude of changes in yields or rainfall. Any change in trends in the crop yields in 2011 (i.e. the year of the pesticide bans) or in 2012 (i.e. the year immediately after the bans) would indicate a potential impact of the bans on the crop yield. By contrast, no change in crop yield trends in the two years indicates no evidence for an impact of the pesticide bans. In the analysis of rainfall, if any change in rainfall trend around the year of pesticide bans is identified, this may confound the impact of pesticide bans on crop yield; for example, an increased rainfall may benefit crop growth and offset any negative effects of pesticide bans.

Analyses were conducted using Joinpoint Trend Analysis Software version 4.9 made available by the National Cancer Institute US National Institute of Health [56]. The yield of eight types of crops and rainfall was used as the dependent variable in separate analyses; the coefficients 
in the models were the annual absolute changes in yields or rainfall per year, respectively. In this study, the number of joinpoints was limited to a maximum of two in each analysis to avoid over-fitting by introducing superfluous joinpoints, based on the recommendation from the Joinpoint Trend Analysis Software website [57]. When conducting multiple tests of hypotheses to identify joinpoints that fit the data best, the joinpoint program applies a correction procedure to maintain the overall probability of a type I error (i.e. concluding that there are one or more joinpoints when there are in fact none) at 0.05 .

\section{Results}

\section{Trends in crop yields}

Overall, there was no statistical evidence of downturns in yields for any of the eight types of crops in 2011 (the year of implementation) or 2012 (the following year) in Kerala, indicating no adverse impact of pesticide bans on crop yields (Fig. 1).

A relatively stable upward trend was observed for the yields of banana, pulses, and rice-they increased 73.3, 26.9 , and $36.4 \mathrm{~kg} /$ hectare annually, respectively (Additional file 1: Table S1). In contrast, a downward trend was observed for cashew with an annual reduction of $23.8 \mathrm{~kg} /$ hectare in 2004-2018; however, no change in yield trend was found in this period. There were fluctuations in the yields of cardamom, plantain, sweet potato, and tapioca, but these changes did not coincide with pesticide bans implementation. A minor decrease in cardamom yields (an annual change of $-3.5 \mathrm{~kg} /$ hectare) was observed between 2004 and 2010, followed by an increase of $44.9 \mathrm{~kg} /$ hectare annually in 2010-2017 and a fall of $210.8 \mathrm{~kg} /$ hectare in 2017-2018. Plantain showed a downward trend with an annual change of $-82.0 \mathrm{~kg} / \mathrm{hec}-$ tare in 2004-2016, with a short-lived rise in 2016-2017 (9874.6 kg/hectare), but resuming to the original level with a $10,029.7 \mathrm{~kg} /$ hectare reduction in the next year. Sweet potato yields showed a sharp rise in 2004-2005 $(11,376.7 \mathrm{~kg} /$ hectare $)$, followed by a steady upward trend until 2018 (an increase of $168.5 \mathrm{~kg} /$ hectare annually). A steady upward trend, with a $1164.4 \mathrm{~kg} /$ hectare increase annually, was observed for Tapioca between 2006 and 2014, followed by a slight decline, with a $136.6 \mathrm{~kg} / \mathrm{hec}-$ tare reduction annually from 2014 until 2018 (Additional file 1: Table S1).

Analysing trends in crop yields by district over the study period showed no potential impact of the pesticide bans on yield across all 14 districts in Kerala, with just two exceptions involving sweet potato yields in two of 14 districts (Additional file 1: Fig. S1). These involved a downward shift of slope in Malappuram from 2011 ( $-22.4 \mathrm{~kg} /$ hectare annually; $95 \% \mathrm{CI}-88.1$ to 43.3$)$ and a drop in Thiruvananthapuram in $2012-2013(-310.1 \mathrm{~kg} /$ hectare; $95 \%$ CI - 317.7 to -302.5 ) (Additional file 1: Table S1).

\section{Trends in rainfall}

There was no evidence for an increase in rainfall around the time of the bans that might have compensated for, and hidden, an adverse effect of the pesticide bans on crop yield. Overall, there was a slow reducing trend in rainfall (annual change $-46.9 \mathrm{~mm}, 95 \% \mathrm{CI}-78.5$, - 15.3) in Kerala over 2004-2018 without a change in rainfall trends in or around the implementation year (2011) (Additional file 1: Table S2); the rainfall fell somewhat in 2008, 2011, and 2015-2016 compared to their preceding years, although joinpoint regression showed no evidence for a change in rainfall trends in these years (Fig. 2).

The steady trend in rainfall was found in most districts; exceptions included four districts (Ernakulam, Idukki, Kozhikode, Wayanad) that showed an overall downward trend, Kannur, which showed a change from a level-off trend to a downward trend in 2013, and Kasargod, which showed a change from an upward trend to a downward trend in 2011 (Fig. 2 and Additional file 1: Table S2). The trend for reduced rainfall across these districts did not appear to be favourable for crop growth.

Analysing district-level yield data, certain shifts in crop yields could be linked to abnormal rainfall in the form of unusually heavy or unexpected showers during certain months, leading to severe floods in 2007 and 2018 that affected crop yields (Additional file 1: Fig. S1). For example, there was a sharp drop in banana yields in Ernakulam (annual change - $2598.6 \mathrm{~kg} /$ hectare) and Thrissur (annual change - $7218 \mathrm{~kg} /$ hectare) in 2017-2018 (Additional file 1: Table S1).

\section{Discussion}

\section{Yield changes of crops grown in Kerala}

In this study, we found no evidence to indicate that the 2011 pesticide bans in Kerala had an adverse effect on crop yields in the state. State-level yields increased for most of the studied crops after the bans, except for cashew, which showed a downward trend prior to the bans. Yields have in general been increasing in India and globally due to a combination of fertilizer use, irrigation, and improvements in crop varieties and farmer management practices [58-61].

State policies and pricing may underlie the decline in cashew yields in Kerala. The crop is not recognised as a plantation crop by the state, resulting in high import duties on cashews and restrictive land ceiling laws that do not apply to plantation crops (such as rubber, which has been replacing cashew) $[62,63]$. Consequently, there has been a trend to grow cashew trees on inferior, less fertile 


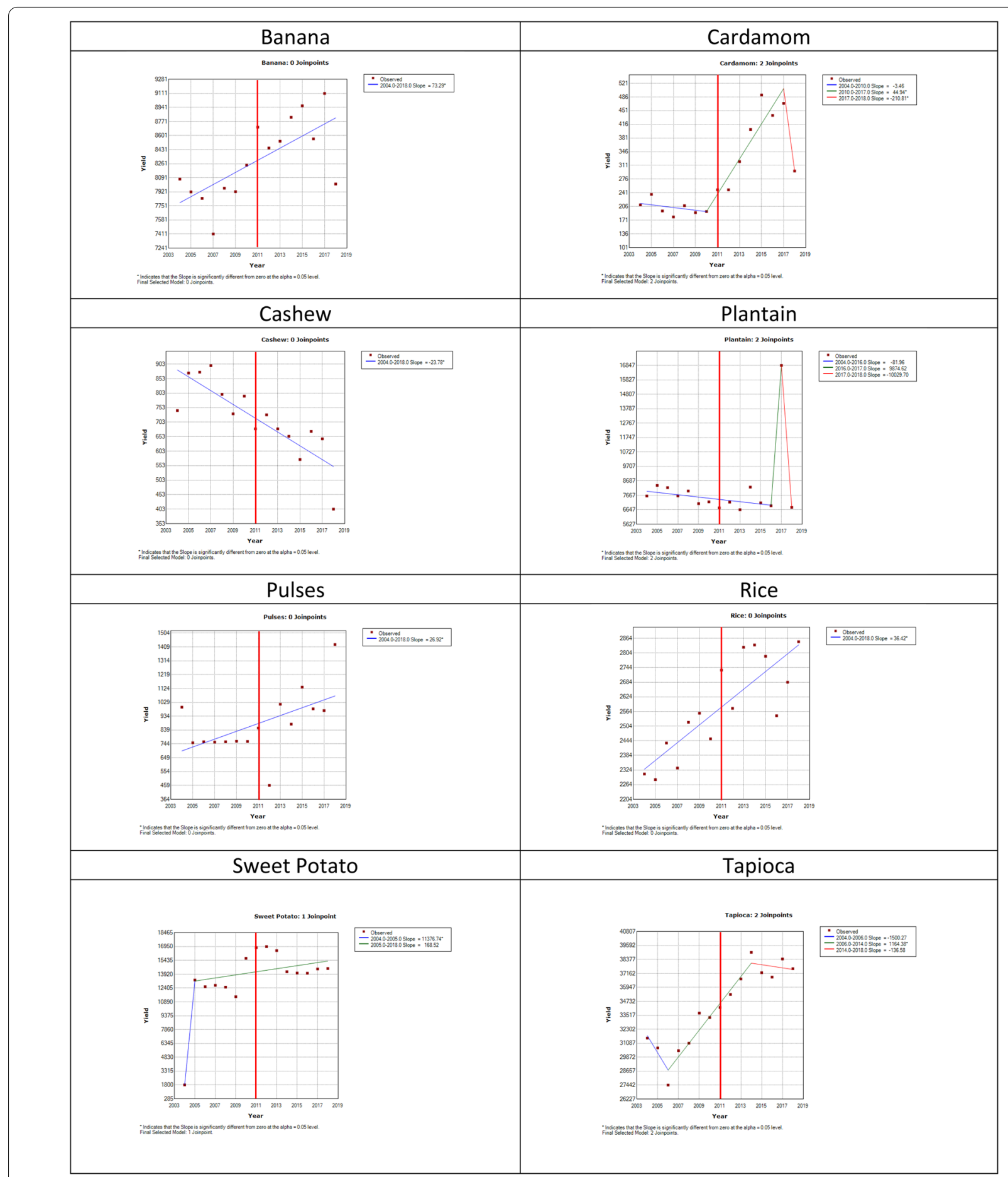

Fig. 1 Trend in the yields of eight crops in Kerala, India, in 2004-2018. Lines are estimated linear trends from joinpoint regression analysis. The vertical line (in red) indicates the year when the pesticide bans were implemented (2011)

land as a supplementary source of income for farmers [64]. Other issues affecting cashew include: unseasonal excessive rainfall leading to high humidity during flowering and fruiting periods and increased fungal disease
[65, 66]; cashew stem and root borer and tea mosquito bug infestations in the north of the state due to inferior quality seeds; improper pest management resulting from labour shortages; and reduced incentives for farmers to 


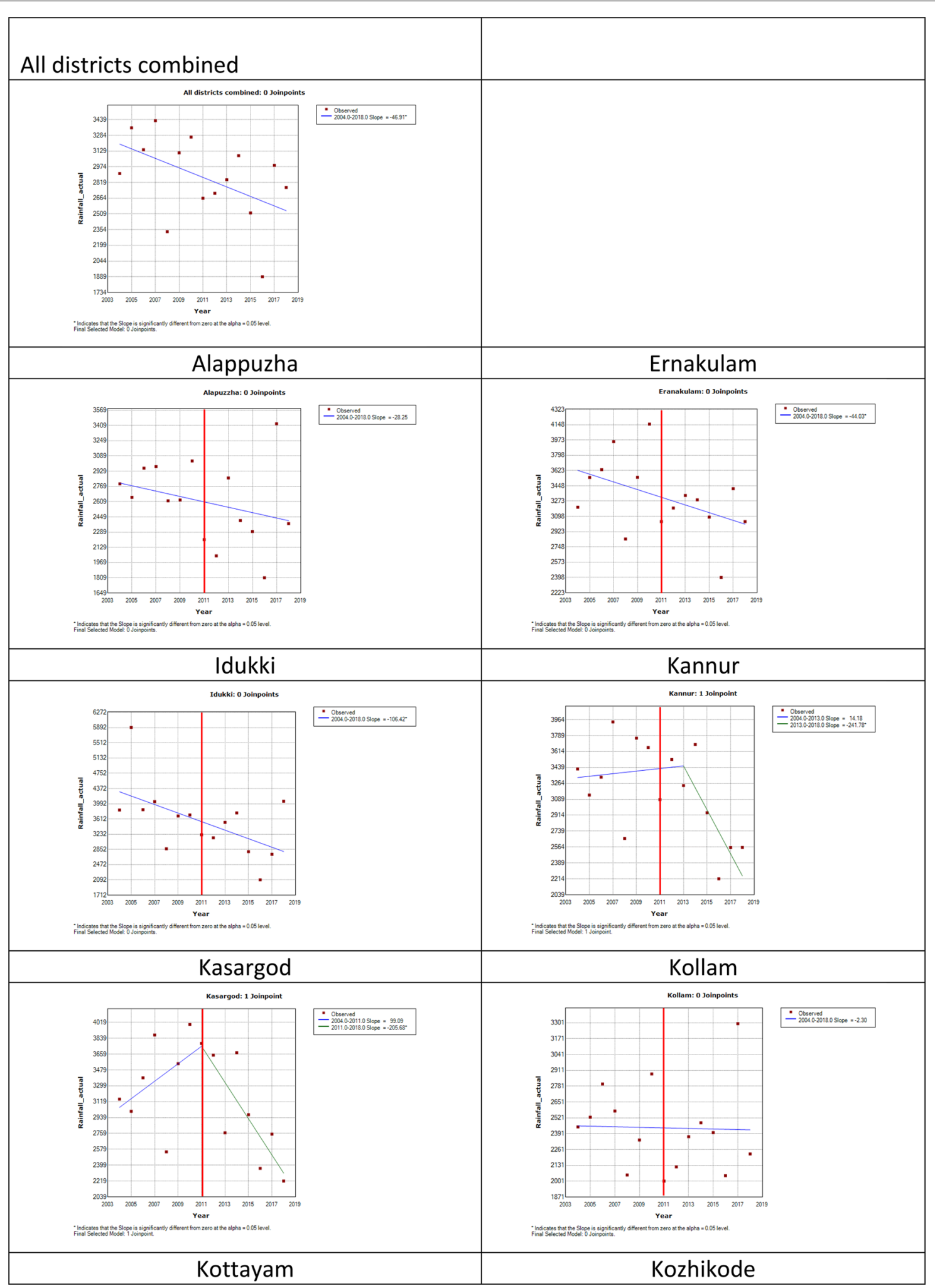

Fig. 2 Trends in rainfall in Kerala, India, in 2004-2018. Lines are estimated linear trends from joinpoint regression analysis. The vertical line (in red) indicates the year when the pesticide bans were implemented (2011) 


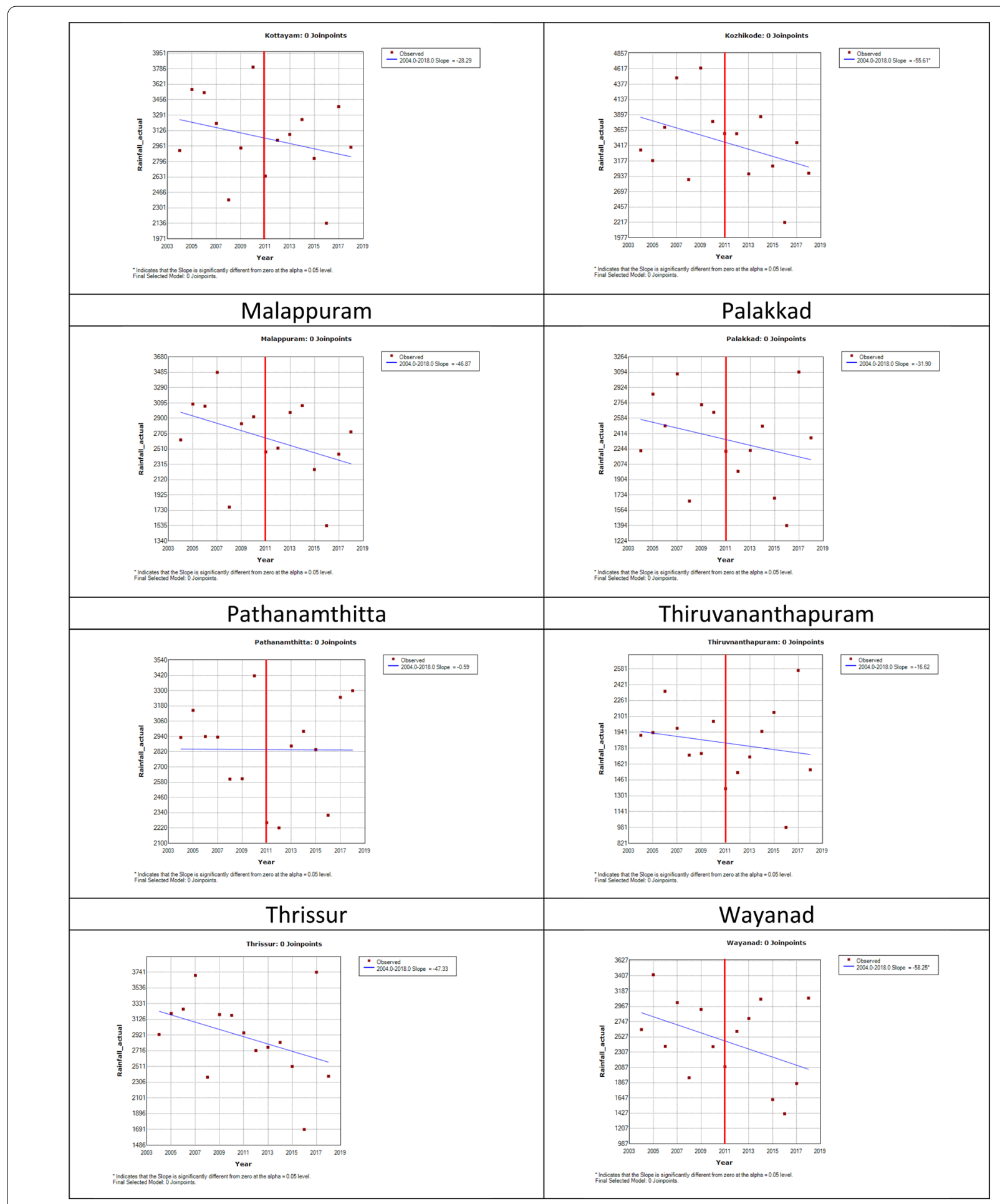

Fig. 2 continued

invest in cashew because of unfavourable crop prices [67]. The state-sanctioned substitute pesticides were found to be effective in research surveys conducted by
Kerala Agricultural University [68]. Mozambique banned highly hazardous pesticides including endosulfan in 2011, but cashew production continued to increase [69, 
70]. Therefore, combined with the pre-existing decline in cashew production, the pesticide bans do not appear to explain the decline in cashew yield.

State government agricultural policies may also have had a role in influencing yields of other crops. Cardamom cultivation was promoted due high value and steady exports, through provision of systematic credit and supply chains for the crop, procurement of highquality seeds [71], and establishment of dedicated 'spice parks' consisting of auction centres, warehouses, banks, and quality assessment facilities [72]. Tapioca is primarily cultivated for household consumption. However, its starch is used in textiles, paper, and pharmaceutical products, leading to a high demand in the manufacturing sector, with moderate export demand [73].

\section{Production of agricultural commodities}

Over the period around the pesticide ban, the production in Kerala of the crops studied was almost constant. Total annual average production increased by less than $1 \%$ or 31,000 tonnes in the period after the ban (2012-2018) compared to the period prior to the ban (2004-2011). This relatively static total hides substantial shifts between crops and reductions in areas under cultivation, with yield improvements acting to offset the smaller cultivated areas (Additional file 1: Table S3).

Food crop production has been impacted by the reduction in area under cultivation, with plantation cash crops (e.g. coconut, rubber) displacing food crops, especially rice $[51,74]$. The area under cultivation declined for all crops in this study from 2004 to 2018 (except banana and plantain which increased by $4.5 \%$ and $8.5 \%$, respectively), dropping overall by $12.5 \%$ between 2004-2011 and 2012-2018. These declines contributed to the state's total cropped area decline over recent decades, from 3,000,000 hectares in 2000 to 2,584,000 hectares in 2016-17 [75]. Rice cultivated area drop by an average of $17.9 \%$ between 2004-2011 and 2012-2018, but offsetting yield increases limited production decline to $8.9 \%$. Similar changes are repeated with higher declines in cultivated area and production for pulses and sweet potato with a fall in production of $38.4 \%$ and 26.1, respectively (Additional file 1: Table S3).

The declining trend in cultivated areas preceded the 2011 bans, due to factors such as reductions in area sown more than once per year and diversion of economic activity from agriculture to non-agricultural operations due to high input prices and labour cost [75]. The state government launched initiatives to promote rice cultivation and other food crops such as millets, pulses, and tubers to achieve greater self-sufficiency in meeting domestic food demand [51, 76, 77]. Kerala produced only $15 \%$ of its total consumption of food grains and $17 \%$ of its required rice, in 2009-2010 [78]. However, despite interventions to increase productivity and encourage farmers to increase the total area under production, there has been a shift from an agrarian economy towards a service sector-based economy since the early 1990s [53]. The declines in the GDP share of agriculture and allied activities, and the high workforce participation in other sectors have led to agricultural labour shortage [75] (Additional file 1: Table S4).

\section{Pesticide regulation and trade}

There is no World Trade Organization (WTO) standard for pesticides associated with the production process or the residues in food commodities. While standards such as the CODEX Alimentarius published jointly by the FAO and WHO [79] are encouraged by the WTO [80], pesticide regulations differ across countries [81]. Maximum residue limit (MRL) pesticide levels and other pesticide regulations are therefore a form of non-tariff measure affecting international trade [82-84], and can potentially be used as a method for protectionism [85].

Crop residues have a major economic impact on exports from India that would be ameliorated by reductions in pesticide use. Rejection of agricultural products exported from India by the importing countries because of MRL exceedances result in loss of income as well as increased costs for re-shipment or destruction of the rejected produce (Box 2). In 2018, over 16\% of Indian farm exports to the European Union (EU) were rejected due to MRL exceedance [86]. India was one of the three countries with most import rejections to the United States of America (USA) due to MRL issues [87]. MRL guidelines are difficult to enforce in India where a large proportion of farmers are illiterate and enforcement difficult [81]. The lack of a ban on toxic pesticides in India has led buyers to shift their sources elsewhere. Countries such as Argentina, Cambodia, Kenya, and Uganda have implemented higher food safety standards resulting to India losing some of its EU market share [88].

A proportion of Indian farm produce sold domestically contains pesticide residues that exceed recommended MRLs [29, 89, 90]. Export produce tends to be more carefully monitored than domestically marketed produce because the cost of rejection is higher. Nevertheless, local populations have an equal right to safe food and the 
removal of hazardous pesticides from food production will benefit all consumers. Kerala is surrounded by other states without pesticide bans, which increases the probability of pesticide 'leakages' from neighbouring areas. The Kerala Agricultural University has launched the 'Safe to Eat' programme to ensure that food produce in Kerala is not contaminated with pesticides from other states [91].

\section{Continued use and impact of highly hazardous pesticides}

Farmers continue to use highly hazardous pesticides in the belief that they will produce better yields [92-94], despite evidence indicating that their use is not essential for maintaining yields [95, 96]. Awareness of, and adherence to, correct spraying protocols is very low among Keralan farm workers [97]. Studies from India show that farmers perceptions regarding pesticide usage are distorted due to high rates of illiteracy and low levels of awareness. Pesticides are erroneously considered to be "plant-growers" as well as "drug treatments" by farmers rather than lethal chemicals to be used judiciously $[26,98,99]$. This also leads to unscientific mixing of pesticides, and spraying them in higher than recommended doses [98]. Although pesticide suicides in Kerala have been declining since the bans in 2005 and 2011, an estimated 541 people still died from pesticide ingestion in 2018 [100, 101].

\section{Limitations}

This study could not establish a direct link between fluctuations in crop yields and pesticide bans due to the lack of primary data studying the effects of the bans. It is possible that other factors have influenced crop yields trends apart from rainfall and pesticide bans. However, there is no reliable quantitative data to analyse the effect of other issues. We relied on secondary research papers and government review reports to explain yield trends. Additionally, data on vegetable production could not be accessed for this paper, meaning that the analysis was limited to major food crops and cash crops.

This paper lacks a comparison state, due to major statelevel differences in crops grown, quality of data collected, state policy, climate, and demographics-all of which confound a comparative analysis. Kerala, in particular due to its geographic location in India and high-quality data available for analysis, is different to other states.

\section{Conclusion}

This study found no evidence that the bans of 14 pesticides in 2011 had any observable adverse impact on agricultural yields in the state of Kerala. This is corroborated by research from other countries in South Asia where similar bans were implemented with no impact on agricultural yields [21, 43, 44]. Various factors such as government schemes, prices in the domestic and international market, seed procurement, and weather conditions were the factors reported to significantly influence area under agriculture and crop yields. This study adds to the evidence that highly hazardous pesticides can be removed from agriculture without affecting crop yields [18].

The Keralan bans were implemented with provision of safer alternatives as recommended by the state government. This example suggests that Indian state and central governments can remove highly hazardous pesticides from agricultural production to improve farm workers safety and food quality, without reducing yields. India took steps in this direction by banning 16 pesticides in 2018 and proposing in 2020 a ban of an additional 27 highly hazardous pesticides $[45,102]$. These progressive measures will help eliminate highly hazardous pesticides, encourage sustainable forms of agriculture, and prevent many deaths from pesticide poisoning.

\section{Box 1: Pesticides banned in Kerala in 2011 and proposed for national bans in 2020}

\begin{tabular}{|c|c|c|}
\hline Pesticide & $\begin{array}{l}\text { Rat oral LD50 } \\
(\mathrm{mg} / \mathrm{kg})\end{array}$ & $\begin{array}{l}\text { WHO hazard } \\
\text { category }\end{array}$ \\
\hline \multicolumn{3}{|l|}{ Kerala } \\
\hline Phorate & 2 & la Extremely hazardous \\
\hline Methyl parathion & 6 & Ib Highly hazardous \\
\hline Carbofuran & 8 & Ib Highly hazardous \\
\hline Monocrotophos & 14 & Ib Highly hazardous \\
\hline Methyl demeton & 40 & $\begin{array}{l}\text { II Moderately hazard- } \\
\text { ous }\end{array}$ \\
\hline Triazophos & 82 & $\begin{array}{l}\text { II Moderately hazard- } \\
\text { ous }\end{array}$ \\
\hline Profenofos & 358 & $\begin{array}{l}\text { II Moderately hazard- } \\
\text { ous }\end{array}$ \\
\hline Edifenphos & 150 & $\begin{array}{l}\text { Il Moderately hazard- } \\
\text { ous }\end{array}$ \\
\hline Tricyclazole & 305 & $\begin{array}{l}\text { Il Moderately hazard- } \\
\text { ous }\end{array}$ \\
\hline Oxythioquinox & 500 & $\begin{array}{l}\text { II Moderately hazard- } \\
\text { ous }\end{array}$ \\
\hline Anilophos & 473 & $\begin{array}{l}\text { II Moderately hazard- } \\
\text { ous }\end{array}$ \\
\hline Paraquat dichloride & 150 & $\begin{array}{l}\text { II Moderately hazard- } \\
\text { ous }\end{array}$ \\
\hline
\end{tabular}




\begin{tabular}{|c|c|c|}
\hline Pesticide & $\begin{array}{l}\text { Rat oral LD50 } \\
(\mathrm{mg} / \mathrm{kg})\end{array}$ & $\begin{array}{l}\text { WHO hazard } \\
\text { category }\end{array}$ \\
\hline Thiobencarb & 1300 & $\begin{array}{l}\text { II Moderately hazard- } \\
\text { ous }\end{array}$ \\
\hline Atrazine & c2000 & III Slightly hazardous \\
\hline \multicolumn{3}{|l|}{ National } \\
\hline Acephate & 945 & $\begin{array}{l}\text { II Moderately hazard- } \\
\text { ous }\end{array}$ \\
\hline Atrazine & c2000 & III Slightly hazardous \\
\hline Benfuracarb & 205 & $\begin{array}{l}\text { ॥l Moderately hazard- } \\
\text { ous }\end{array}$ \\
\hline Butachlor & 3300 & III Slightly hazardous \\
\hline Captan & 9000 & $U^{*}$ \\
\hline Carbendazim & $>10,000$ & U \\
\hline Carbofuran & 8 & Ib Highly hazardous \\
\hline Chlorpyrifos & 135 & $\begin{array}{l}\text { II Moderately hazard- } \\
\text { ous }\end{array}$ \\
\hline $\begin{array}{l}\text { 2,4-Dichlorophenoxy acetic } \\
\text { acid }\end{array}$ & 375 & $\begin{array}{l}\text { ॥l Moderately hazard- } \\
\text { ous }\end{array}$ \\
\hline Deltamethrin & c135 & $\begin{array}{l}\text { II Moderately hazard- } \\
\text { ous }\end{array}$ \\
\hline Dicofol & c690 & $\begin{array}{l}\text { ॥l Moderately hazard- } \\
\text { ous }\end{array}$ \\
\hline Dimethoate & c150 & $\begin{array}{l}\text { ॥l Moderately hazard- } \\
\text { ous }\end{array}$ \\
\hline Dinocap & 980 & $\begin{array}{l}\text { II Moderately hazard- } \\
\text { ous }\end{array}$ \\
\hline Diuron & 3400 & III Slightly hazardous \\
\hline Malathion & $c 2100$ & III \\
\hline Mancozeb & $>8000$ & U \\
\hline Methomyl & 17 & Ib Highly hazardous \\
\hline Monocrotophos & 14 & Ib Highly hazardous \\
\hline Oxyfluorfen & $>5000$ & U \\
\hline Pendimethalin & 1050 & $\begin{array}{l}\text { ॥l Moderately hazard- } \\
\text { ous }\end{array}$ \\
\hline Quinalphos & 62 & $\begin{array}{l}\text { II Moderately hazard- } \\
\text { ous }\end{array}$ \\
\hline Sulfosulfuron & & Not listed \\
\hline Thiodicarb & 66 & $\begin{array}{l}\text { ॥l Moderately hazard- } \\
\text { ous }\end{array}$ \\
\hline Thiophanate-methyl & $>5000$ & $U$ \\
\hline Thiram & 560 & $\begin{array}{l}\text { ॥l Moderately hazard- } \\
\text { ous }\end{array}$ \\
\hline Zineb & $>5000$ & U \\
\hline Ziram & 1400 & $\begin{array}{l}\text { II Moderately hazard- } \\
\text { ous }\end{array}$ \\
\hline
\end{tabular}

Source: The WHO Recommended Classification of Pesticides by Hazard and Guidelines to Classification 2019 [3]

LD50 $=$ dose at which $50 \%$ of animals die

According to the Indian Insecticides Act of 1968, pesticides are classified as red, yellow, blue, and green depending on their lethality. Red-labelled pesticides are extremely toxic (oral lethal dose: $1-50 \mathrm{mg} / \mathrm{kg}$ ) while yellowlabelled pesticides are highly toxic (oral lethal dose: $51-500 \mathrm{mg} / \mathrm{kg}$ )

*U—unlikely to present acute hazard in normal use

\section{Box 2}

Saudi Arabia, which purchases $85 \%$ of Indian cardamom exports, detained four consignments due to the detection of pesticide residue above the MRL as specified by Saudi Arabia Food and Drug Authority in April-May 2018 [103]. Cardamom prices were severely hit and the Indian government had to step in with integrated pest management (IPM) techniques to avoid future incidents of export rejection. Despite this, cardamom continues to have high pesticide residues [104] and Keralan cultivators have been noted to smuggle in banned pesticides from neighbouring states $[105,106]$. Owing to this, Saudi Arabia put a moratorium on Indian cardamom exports in August 2020 [107], with particularly severe effects for Kerala [108].

\section{Supplementary Information}

The online version contains supplementary material available at https://doi. org/10.1186/s40066-021-00348-z.

Additional file 1: Table S1. Results of joinpoint regression analysis of trends in crop yields, by crop type and district, in Kerala, India, in 2004-2018. Table S2. Results of joinpoint regression analysis of rainfall by district in Kerala, India, in 2004-2018. Table S3. Changes in average area under cultivation (hectares) and total production for each crop (tonnes), before and after the 2011 pesticide bans. Table S4. Shares of different sectors in Gross Value Added (GVA) and Employment, Kerala and India (2017-18). Figure S1. Trends in crop yields by district over the study period (2004-2018).

\section{Acknowledgements}

The authors would like to thank the National Crime Records Bureau, the Kerala State Planning Board, and the Department of Economics and Statistics, Government of Kerala, for provision of data. The Centre for Pesticide Suicide Prevention is funded by an Incubator Grant from the Open Philanthropy Project Fund, an advised fund of Silicon Valley Community Foundation, on the recommendation of GiveWell, USA.

\section{Authors' contributions}

Conceptualisation: ME, MD, and AS; statistical methodology: SSC and CYL; data analysis: AS, SSC, and CYL; writing: AS, ME, PA; writing — review and editing: $M E, M D, I M$, and SSC. All authors read and approved the final manuscript.

\section{Funding}

Not applicable.

\section{Availability of data and materials}

Data and materials for this study are available and will be provided to the journal upon request.

\section{Declarations}

Ethics approval and consent to participate Not applicable

\section{Consent for publication}

Not applicable

\section{Competing interests}

The authors declare no conflict of interests. 


\section{Author details}

${ }^{1}$ Centre for Pesticide Suicide Prevention, University of Edinburgh, Edinburgh, UK. ${ }^{2}$ Institute of Health Behaviors and Community Sciences, College of Public Health, National Taiwan University, Taipei, Taiwan. ${ }^{3}$ Department of General Medicine, Government Medical College, Thrissur, Kerala, India. ${ }^{4}$ Global Academy of Agriculture and Food Security, The Royal (Dick) School of Veterinary Studies, University of Edinburgh, Edinburgh, UK. ${ }^{5} \mathrm{Global}$ Health Program, College of Public Health, National Taiwan University, Taipei, Taiwan. ${ }^{6}$ Psychiatric Research Center, Wan Fang Hospital, Taipei Medical University, Taipei, Taiwan.

Received: 8 February 2021 Accepted: 19 November 2021

Published online: 22 January 2022

\section{References}

1. United Nations Human Rights Council: Report of the Special Rapporteur on the issue of human rights obligations relating to the enjoyment of a safe, clean, healthy and sustainable environment; 2016. https:// undocs.org/A/HRC/37/59.

2. Potts SG, Imperatriz Fonseca V, Ngo HT, Biesmeijer JC, Breeze TD, Dicks L, Garibaldi LA, Hill R, Settele J, Vanbergen AJ: Summary for policymak ers of the assessment report of the Intergovernmental Science-Policy Platform on Biodiversity and Ecosystem Services on pollinators, pollination and food production: IPBES; 2016. https://ipbes.net/assessmentreports/pollinators

3. World Health Organization. The WHO recommended classification of pesticides by hazard and guidelines to classification 2019. Geneva: World Health Organization; 2019. https://apps.who.int/iris/bitstream/ handle/10665/332193/9789240005662-eng.pdf.

4. Gunnell D, Fernando R, Hewagama M, Priyangika WD, Konradsen F, Eddleston M. The impact of pesticide regulations on suicide in Sri Lanka. Int J Epidemiol. 2007;36(6):1235-42.

5. Chowdhury FR, Dewan G, Verma VR, Knipe DW, Isha IT, Faiz MA, Gunnell DJ, Eddleston M. Bans of WHO Class I Pesticides in Bangladesh-suicide prevention without hampering agricultural output. Int J Epidemiol. 2018;47(1):175-84.

6. Dhananjayan V, Ravichandran B. Occupational health risk of farmers exposed to pesticides in agricultural activities. Curr Opin Environ Sci Health. 2018:4:31-7.

7. Ye M, Beach J, Martin JW, Senthilselvan A. Occupational pesticide exposures and respiratory health. Int J Environ Res Public Health. 2013;10(12):6442-71.

8. Birthal P, Sharma O, Kumar S. Economics of integrated pest management: evidences and issues. Indian J Agric Econ. 2000;55(4):644-59.

9. Tamizheniyan S, Umesh K, Krishna W. Integrated pest management in rice production in Tamil Nadu: a resource economics analysis. Agric Econ Res Rev. 2003;16(1):1-10.

10. Patil S, Reidsma P, Shah P, Purushothaman S, Wolf J. Comparing conventional and organic agriculture in Karnataka, India: where and when can organic farming be sustainable? Land Use Policy. 2014;37:40-51.

11. Saurabh Tripathi SN, Shahidi T. Zero budget natural farming for the sustainable development goals: Andhra Pradesh, India: Council on Energy EaW; 2018. https://www.ceew.in/sites/default/files/CEEW-Zero-BudgetNatural-Farming-and-SDGs-Issue-Brief-25Jan18_0.pdf.

12. Mew EJ, Padmanathan P, Konradsen F, Eddleston M, Chang SS, Phillips MR, Gunnell D. The global burden of fatal self-poisoning with pesticides 2006-15: systematic review. J Affect Disord. 2017;219:93-104.

13. National Crime Records Bureau. Distribution of suicides by means/ mode adopted during 2019. Edited by Ministry of Home Affairs. New Delhi: Government of India; 2019.

14. Gunnell D, Eddleston M, Phillips MR, Konradsen F. The global distribution of fatal pesticide self-poisoning: systematic review. BMC Public Health. 2007;7:357.

15. Yip PSF, Caine E, Yousuf S, Chang S-S, Wu KC-C, Wu Y-Y. Means restriction for suicide prevention. Lancet. 2012;379(9834):2393-9.

16. World Health Organization \& Food and Agriculture Organization of the United Nations: Preventing suicide: a resource for pesticide registrars and regulators. Geneva:WHO; 2019. https://apps.who.int/iris/handle/ $10665 / 326947$.
17. Eddleston M, Gunnell D. Preventing suicide through pesticide regulation. Lancet Psychiatry. 2020;7(1):9-11.

18. Gunnell D, Knipe D, Chang SS, Pearson M, Konradsen F, Lee WJ, Eddleston M. Prevention of suicide with regulations aimed at restricting access to highly hazardous pesticides: a systematic review of the international evidence. Lancet Glob Health. 2017;5(10):e1026-37.

19. Knipe DW, Gunnell D, Eddleston M. Preventing deaths from pesticide self-poisoning-learning from Sri Lanka's success. Lancet Glob Health. 2017;5(7):e651-2.

20. Bonvoisin T, Utyasheva L, Knipe D, Gunnell D, Eddleston M. Suicide by pesticide poisoning in India: a review of pesticide regulations and their impact on suicide trends. BMC Public Health. 2020;20(1):251.

21. Cha ES, Chang SS, Gunnell D, Eddleston M, Khang YH, Lee WJ. Impact of paraquat regulation on suicide in South Korea. Int J Epidemiol. 2016;45(2):470-9. https://doi.org/10.1093/ije/dyv304

22. Chang SS, Lin CY, Lee MB, Shen LJ, Gunnell D, Eddleston M. The early impact of paraquat ban on suicide in Taiwan. Clin Toxicol (Phila). 2021:1-5.

23. Gunnell D, Eddleston M. Suicide by intentional ingestion of pesticides: a continuing tragedy in developing countries. Int J Epidemiol. 2003;32(6):902-9.

24. Chakraborty S, Mukherjee S, Roychoudhury S, Siddique S, Lahiri T, Ray MR. Chronic exposures to cholinesterase-inhibiting pesticides adversely affect respiratory health of agricultural workers in India. J Occup Health. 2009:51(6):488-97.

25. Kori R, Thakur R, Kumar R, Yadav R. Assessment of adverse health effects among chronic pesticide-exposed farm workers in Sagar District of Madhya Pradesh, India. Int J Nutr Pharmacol Neurol Dis. 2018:8(4):153-61.

26. Sai MVS, Revati GD, Ramya R, Swaroop AM, Maheswari E, Kumar MM. Knowledge and perception of farmers regarding pesticide usage in a rural farming village, Southern India. Indian J Occup Environ Med. 2019;23(1):32

27. Patil DA, Katti RJ. Modern agriculture, pesticides and human health: a case of agricultural labourers in western Maharashtra. J Rural Dev. 2012;31(3):305-18.

28. Mittal S, Kaur G, Vishwakarma GS. Effects of environmental pesticides on the health of rural communities in the Malwa Region of Punjab, India: a review. Hum Ecol Risk Assess Int J. 2014;20(2):366-87.

29. Kumari D, John $\mathrm{S}$. Health risk assessment of pesticide residues in fruits and vegetables from farms and markets of Western Indian Himalayan region. Chemosphere. 2019;224:162-7.

30. Thakur J, Rao B, Rajwanshi A, Parwana H, Kumar R. Epidemiological study of high cancer among rural agricultural community of Punjab in Northern India. Int J Environ Res Public Health. 2008;5(5):399-407.

31. Bhat AR, Wani MA, Kirmani A. Brain cancer and pesticide relationship in orchard farmers of Kashmir. Indian J Occup Environ Med. 2010;14(3):78.

32. Ministry of Agriculture and Farmers Welfare. Monitoring of pesticide residues at national level_annual progress report (April, 2014-March, 2015). New Delhi; 2015.

33. Rao J. Andhra Pradesh and Telangana suffer from high pesticide residues. Deccan Chronicle. 2016, Oct 18. https://www.deccanchronicle. com/nation/current-affairs/181016/andhra-pradesh-and-telanganasuffer-from-highpesticide-residues.html. Accessed Nov 2021

34. United Nations Environment Programme. Environmental and health impacts of pesticides and fertilizers and ways of minimizing them; 2021 https://wedocs.unep.org/xmlui/bitstream/handle/20.500.11822/34463/ JSUNEPPF.pdf? sequence $=13$.

35. United Nations Environment Programme: Bees, Bans and Broad-Spectrum Pesticides. 2021. https://www.unep.org/news-and-stories/story/ bees-bans-and-broad-spectrum-pesticides.

36. van der Werf HMG. Assessing the impact of pesticides on the environment. Agr Ecosyst Environ. 1996;60(2):81-96.

37. Krauss J, Gallenberger I, Steffan-Dewenter I. Decreased functional diversity and biological pest control in conventional compared to organic crop fields. PLoS ONE. 2011;6(5): e19502.

38. Hole DG, Perkins AJ, Wilson JD, Alexander IH, Grice PV, Evans AD. Does organic farming benefit biodiversity? Biol Cons. 2005;122(1):113-30.

39. Rahul N. Centre urged to rethink on ban of pesticides. The Hindu. 2020 July 27. https://www.thehindu.com/news/national/telangana/centreurged-to-rethink-on-ban-of-pesticides/article32203800.ece. 
40. Agarwal RG. Pesticides to play crucial role of crop insurance as India strives to boost agriculture. Financial Express. 2020 Oct 17. https:// www.financialexpress.com/economy/pesticides-to-play-crucial-roleof-crop-insurance-as-india-strives-boost-agriculture-farm-sector-econo my/2107780/. Accessed Dec 2020.

41. Kamila R. Union govt. requested to put on hold draft order banning 27 pesticides. The Hindu. 2020 Jun 12. https://www.thehindu.com/news/ national/karnataka/union-govt-requested-to-put-on-hold-draft-orderbanning-27-pesticides/article31813482.ece. Accessed Oct 2020.

42. Baldos ULC, Hertel TW. The role of international trade in managing food security risks from climate change. Food Secur. 2015;7(2):275-90.

43. Dasgupta S, Meisner C, Wheeler D. Is environmentally-friendly agriculture less profitable for farmers? Evidence on integrated pest management in Bangladesh: The World Bank; 2004.

44. Manuweera G, Eddleston M, Egodage S, Buckley NA. Do targeted bans of insecticides to prevent deaths from self-poisoning result in reduced agricultural output? Environ Health Perspect. 2008;116(4):492-5.

45. Ministry of Agriculture and Farmers Welfare. The Gazette of India: extraordinary; PART II-Section 3-Sub-section (ii), No. 1351. New Delhi: Government of India; 2020. http://egazette.nic.in/WriteReadD ata/2020/219423.pdf.

46. Kulkarni V. Govt moves to ban 27 pesticides; 'baffled' industry says it will oppose the order. Business Line. 2020 May 19. https://www.thehindubu sinessline.com/economy/agri-business/govt-moves-to-ban-27-pesti cides-baffled-industry-says-it-will-oppose-the-order/article31626320. ece. Accessed Nov 2020

47. Wadke R. Pesticide to tackle locust attacks to be banned from December 31. Business Line. 2020 Feb 23. https://www.thehindubusinessline. com/economy/agri-business/pesticide-to-tackle-locusts-attacks-to-bebanned-from-december-31/article30894172.ece. Accessed Nov 2020.

48. Government of Kerala. Substitutes for pesticides banned by Govt of Kerala vide G.O. (MS) No. 116/2011/ Agri dated 7-5-2011; 2011. https:// keralaagriculture.gov.in/wp-content/uploads/2019/01/go_and_circu lar/GO_MS_116_B.pdf.

49. Government of India: Economic Survey 2019-2020, vol. II. New Delhi; 2019-20. https://www.indiabudget.gov.in/economicsurvey/doc/vol2c hapter/echap07_vol2.pdf.

50. Nair PS. Understanding below-replacement fertility in Kerala, India. J Health Popul Nutr. 2010;28(4):405-12.

51. Kerala State Planning Board. Economic Review 2019. Edited by Department of Planning. Thiruvananthapuram: Government of Kerala; 2019: $61-78$.

52. Department of Economics and Statistics. Report on Agricultural Statistics, vol. 2019; 2004-2018. http://www.ecostat.kerala.gov.in/index.php/ agricultures.

53. Kerala State Planning Board. Economic review archives (1959-2015). Thiruvananthapuram: Government of Kerala.

54. Kim H-J, Fay MP, Feuer EJ, Midthune DN. Permutation tests for joinpoint regression with applications to cancer rates. Stat Med. 2000;19(3):335-51.

55. Lerman PM. Fitting segmented regression models by grid search. J R Stat Soc Ser C (Appl Stat). 1980;29(1):77-84.

56. Joinpoint regression program http://srab.cancer.gov/joinpoint. Accessed March 18.

57. National Cancer Institute. Joinpoint Trend Analysis Software. Division of Cancer Control and Population Sciences; 2021.

58. Zaveri E, Lobell DB. The role of irrigation in changing wheat yields and heat sensitivity in India. Nat Commun. 2019;10(1):4144.

59. Eliazer Nelson ARL, Ravichandran K, Antony U. The impact of the Green Revolution on indigenous crops of India. J Ethnic Foods. 2019;6(1):8.

60. Madhukar A, Kumar V, Dashora K. Spatial and temporal trends in the yields of three major crops: wheat, rice and maize in India. Int J Plant Prod. 2020;14(2):187-207.

61. Alexander P, Rounsevell MDA, Dislich C, Dodson JR, Engström K, Moran D. Drivers for global agricultural land use change: the nexus of diet, population, yield and bioenergy. Glob Environ Chang. 2015:35:138-47.

62. Prakash M. In 2 years, $80 \%$ cashew producing units closed in Kollam. Down to Earth. https://www.downtoearth.org.in/news/agriculture/in-2years-80-cashew-producing-units-closed-in-kollam-61749. Accessed June 2020.
63. Dr.T.Sisili: Analysis of Cashew nut production in Kerala State. International Journal of Advance Research and Innovative Ideas in Education 2017, 3(6):568-576. http://ijariie.com/AdminUploadPdf/Analysis_of_ Cashew_nut_production_in_Kerala_State_ijariie6991.pdf

64. Kumar BBJ, Salim AA. Performance of area, production and productivity of cashew in India and Kerala. Productivity. 2019;60(1):88-95.

65. Eapen M, Jeyaranjan J, Harilal KN, Swaminathan P, Kanji N. A case study of the cashew processing sector; 2003. http://www.jstor.org.ezproxy.is. ed.ac.uk/stable/resrep18073.8.

66. Rupa TR, Rejani R, Bhat MG. Impact of climate change on cashew and adaptation strategies. In: Singh HCP, Rao NKS, Shivashankar KS, editors. Climate-resilient horticulture: adaptation and mitigation strategies. India: Springer India; 2013. p. 189-98.

67. Sajeev M, Manjusha AM. Decline of cashew (Anacardium occidentale) cultivation in North Kerala: an analysis of the impact, its determinants and constraints. Indian Res J Ext Educ. 2016;16(3):25-32.

68. Santhosh K. Organic substitutes for endosulfan effective: KAU. The Hindu. 2013 July 27. https://www.thehindu.com/news/national/kerala/ organic-substitutes-for-endosulfan-effective-kau/article4959501.ece. Accessed Nov 2020

69. Food and Agriculture Organization of the United Nations. Mozambique prohibits highly hazardous pesticides. vol. 2021.

70. Food and Agriculture Organization of the United Nations: FAOSTAT. Food and Agricultural Organization of the United Nations; 2000-2015.

71. Mishra DP, Mishra SP, Mishra N. The enhanced inland food chain and export disparities of small cardamoms in India: a critical. 2018.

72. Hameedu MS. Supply chain analysis of cardamom in Kerala. Int J Sci Res Publ. 2014;4(3):1-7.

73. Varmudy V: Cassava Cultivation and Export: Vast Scope in India. Facts For You. 2014: 22-25. https://ffymag.com/admin/issuepdf/22-25_Cassa va FFYJan-14.pdf

74. Kerala State Planning Board. Economic review 2016. Edited by Department of Planning. Thiruvananthapuram: Government of Kerala; 2016.

75. Kerala State Planning Board. Economic Review 2017. Edited by Department of Planning. Thiruvananthapuram: Government of Kerala; 2017.

76. Thomas JJ. Paddy cultivation in Kerala. Rev Agrar Stud. 2011;1(2):215-26.

77. Karunakaran N. Paddy cultivation in Kerala-trends, determinants and effects on food security. Artha J Soc Sci. 2014;13(4):21-36.

78. Amiri AH, Delfan B, Jaferian S. Paraquat poisoning cases treated at Shohada Ashayer hospital of Khorramabad in 2001-2006. Res J Biol Sci. 2008;3(5):525-9.

79. Food and Agriculture Organization of the United Nations; World Health Organisation: Codex Alimentarius: International Food Standards.

80. World Trade Organisation. Pesticide residues top of agenda of WTO food safety body Accessed: Oct 2021. Available from: https://www.wto. org/english/news_e/news17_e/sps_02nov17_e.htm.

81. Handford CE, Elliott CT, Campbell K. A review of the global pesticide legislation and the scale of challenge in reaching the global harmonization of food safety standards. Integr Environ Assess Manag. 2015;11(4):525-36.

82. Beghin JC, Schweizer H. Agricultural trade costs. Appl Econ Perspect Policy. 2021;43(2):500-30.

83. Santeramo FG, Lamonaca E. The effects of non-tariff measures on agrifood trade: a review and meta-analysis of empirical evidence. J Agric Econ. 2019;70(3):595-617.

84. Swinnen J. Economics and politics of food standards, trade, and development\#. Agric Econ. 2016;47(S1):7-19.

85. Li Y, Beghin JC. Protectionism indices for non-tariff measures: An application to maximum residue levels. In: Nontariff measures and international trade. World Scientific; 2017. 167-178.

86. Medina-Pastor P, Triacchini G. The 2018 European Union report on pesticide residues in food. EFSA J. 2020. https://doi.org/10.2903/j.efsa. 2020.6057.

87. Bovay J: FDA Refusals of Imported Food Products by Country and Category, 2005-2013: United States Department of Agriculture; 2016. Available from: https://www.ers.usda.gov/webdocs/publications/ 44066/57014_eib151.pdf

88. Goyal TM, Mukherjee A, Kapoor A: Working Paper No. 345: India's exports of food products: Food safety related issues and way forward. Indian Council For Research On International Economic Relations; 2017. Available from: https://icrier.org/pdf/Working_Paper_345.pdf 
89. Nishant N, Upadhyay R. Presence of pesticide residue in vegetable crops: a review. Agric Rev. 2016;37(3):173-85.

90. Grewal A. Pesticide residues in food grains, vegetables and fruits: a hazard to human health. J Med Chem Toxicol. 2017;2(1):1-7.

91. Department of Agriculture and Kerala Agricultural University: a step closer to 'safe to eat food'. Government of Kerala; 2013.

92. Kumar $\bigvee$, Kumar P. Pesticides in agriculture and environment: impacts on human health. Contam Agric Environ Health Risks Remediat. 2019:1:76.

93. Bhardwaj T, Sharma J. Impact of pesticides application in agricultural industry: an Indian scenario. Int J Agric Food Sci Technol. 2013;4(8):817-22.

94. Yadav IC, Devi NL, Syed JH, Cheng Z, Li J, Zhang G, Jones KC. Current status of persistent organic pesticides residues in air, water, and soil, and their possible effect on neighboring countries: a comprehensive review of India. Sci Total Environ. 2015;511:123-37.

95. Luis A, Bravo-Ureta BE, von Cramon-Taubadel S, Hasiner E. The performance of natural resource management interventions in agriculture: evidence from alternative meta-regression analyses. Ecol Econ. 2020;171: 106605

96. Pretty JN, Noble AD, Bossio D, Dixon J, Hine RE, Penning de Vries FWT, Morison JIL: Resource-Conserving Agriculture Increases Yields in Developing Countries. Environm Sci Technol 2006, 40(4):1114-1119. https:// pubs.acs.org/doi/10.1021/es051670d

97. Devi PI. Pesticides in agriculture - a boon or a curse? A case study of Kerala. Econ Political Wkly. 2010;45(26/27):199-207.

98. Shetty $P$, Murugan $M$, Hiremath $M$, Sreeja KG: Farmers' education and perception on pesticide use and crop economies in Indian agriculture. J Experim Sci 2010, 1(1):3-8. http://eprints.nias.res.in/201/

99. Bond J, Kriesemer S, Emborg J, Chadha M. Understanding farmers' pesticide use in Jharkhand India. Ext Farm Syst J. 2009;5(1):53-61.

100. National Crime Records Bureau. Accidental deaths and suicides in India-2018. Edited by Ministry of Home Affairs. New Delhi; 2018: 195-209.

101. National Crime Records Bureau. Distribution of suicides by means adopted — 2004 (State, UT \& City-wise). New Delhi: Government of India; 2004. https://ncrb.gov.in/sites/default/files/adsi_reports_previ ous_year/Table\%202.14_2004.pdf.

102. Ministry of Agriculture and Farmers Welfare. The Gazette of India: extraordinary; PART II-Section 3-Sub-section (ii), No. 3156. New Delhi: Government of India; 2018. http://agricoop.nic.in/sites/default/ files/18\%20pesticde\%20banning\%20188458.pdf.

103. Mohan C. No ban imposed by Japan and Saudi Arabia on India cardamom shipments. Krishi Jagran. 2019 July 25. https://krishijagran.com/ commodity-news/no-ban-imposed-by-japan-and-saudi-arabia-onindia-cardamom-shipments/. Accessed Nov 2020.

104. Murugan M, Ravi R, Anandhi A, Kurien S, Dhanya M. Pesticide use in Indian cardamom needs change in cultivation practices. Curr Sci. 2017;113(6):1058.

105. Raman GK. Banned pesticides used rampantly on cardamom. The Hindu. 2019. https://www.thehindu.com/news/national/kerala/ banned-pesticides-used-rampantly-on-cardamom/article28872924 ece. Accessed 21 Nov 2020.

106. Raman GK. Cardamom growers resort to use of banned pesticides. The Hindu. 2018. https://www.thehindu.com/news/national/kerala/carda mom-growers-resort-to-use-of-banned-pesticides/article22386069.ece. Accessed 20 Oct 2020.

107. Sally M. Cardamom exports to Saudi Arabia stall over chemical residue norms. The Economic Times. 2020 Aug 13. https://economictimes.india times.com/news/economy/foreign-trade/cardamom-exports-to-saudiarabia-stall-over-chemical-residue-norms/articleshow/77528703.cms. Accessed Nov 2020.

108. Raman GK. With no auction, cardamom piles up. The Hindu. 2020 April 3. https://www.thehindu.com/news/national/kerala/with-no-auctioncardamom-piles-up/article31252571.ece. Accessed Nov 2020.

\section{Publisher's Note}

Springer Nature remains neutral with regard to jurisdictional claims in published maps and institutional affiliations.

Ready to submit your research? Choose BMC and benefit from:

- fast, convenient online submission

- thorough peer review by experienced researchers in your field

- rapid publication on acceptance

- support for research data, including large and complex data types

- gold Open Access which fosters wider collaboration and increased citations

- maximum visibility for your research: over $100 \mathrm{M}$ website views per year

At BMC, research is always in progress.

Learn more biomedcentral.com/submissions 